\title{
Hypogammaglobulinemia Prevelance in Children with Atopic Dermatitis and the Relationship Between Immunoglobulin Levels and Eczema Severity
}

\author{
Atopik Dermatitli Çocuklarda Hipogamaglobulinemi Sıkıı̆ı ve Immünglobulin Düzeylerinin \\ Egzama Şiddeti ile Ilişkisi
}

\author{
(D) Burçin BEKEN, (D) Velat ÇELIK, (D) Pınar GÖKMIRZA ÖZDEMIR, (D) Mehtap YAZICIOĞLU \\ Trakya University Faculty of Medicine, Department of Pediatrics, Department of Pediatric Immunology and Allergy, Edirne, Turkey
}

\begin{abstract}
Aim: Atopic dermatitis (AD) is the most common chronic skin disease of childhood. Although eczema may be a prominent finding in some primary immune deficiencies, there are very few studies conducted on the frequency of hypogammaglobulinemia in patients with eczema. In our study, we aimed to determine the frequency of hypogammaglobulinemia in patients with $A D$ and the relationship between immunoglobulin levels and eczema severity.

Materials and Methods: Patients between the ages of 0-18 years, who were diagnosed with AD between January 2015 and August 2018 in the Department Pediatrics Division of Pediatric Allergy and Immunology, Trakya University Faculty of Medicine, were included in the study. Hypogammaglobulinemia was defined as being less than -2 standard deviation of immunoglobulin $A, M$ and $G$ from normal values for age.

Results: The median age of 117 patients included in the study was 11 months [interquartile range (IQR): 6.7-33 months], the median age of eczema onset was 3.5 months (IOR: 2-6 months), the median SCORingAtopicDermatitis at presentation was 13.8 (IQR): 5-32]. Thirty-six (30.8\%) patients had low levels in one of the immunoglobulin isotypes and decreased levels of immunoglobulin $A(\lg A), M$ and $G$ were found in $21(17.9 \%), 18$ $(15.5 \%)$ and $23(19.7 \%)$ patients, respectively. While there was no difference between mild and moderate-severe eczema groups in terms of age at presentation, age of onset of eczema, family history of allergic diseases, smoking exposure, aeroallergen sensitivity, food allergy, the number of patients having hypogammaglobulinemia, and the levels of $\lg A, M$ and $G$, a male predominance and higher number of eosinophils were observed in the moderate-severe eczema group.

Conclusion: It is concluded that the evaluation of immunoglobulin levels independent of the severity of eczema is important for the distinction of primary immunodeficiency and the follow-up of patients in terms of transient hypogammaglobulinemia of infancy in patients with AD.
\end{abstract}

Keywords: Atopic dermatitis, eczema, hypogammaglobulinemia

\section{ÖZ}

Amaç: Atopik dermatit (AD) çocukluk çağının en sık görülen kronik deri hastalığıdır. Bazı primer immün yetmezliklerde egzama belirgin bir bulgu olarak karşımıza çıkabilmekle birlikte egzamalı hastalarda hipogamaglobülinemi sıklığı ile ilgili yapılmış çok az sayıda çalışma bulunmaktadır. Çalışmamızda AD'li hastalarda hipogamaglobülinemi sıklığının ve immünoglobulin düzeylerinin egzama şiddeti ile ilişkisinin belirlenmesi amaçlanmıştır.

Gereç ve Yöntem: Trakya Üniversitesi Tıp Fakültesi, Çocuk Sağlığı ve Hastalıkları Anabilim Dalı, Çocuk İmmünoloji ve Alerji Bölümü'nde Ocak 2015-Ağustos 2018 tarihleri arasında AD tanısı konulan 0-18 yaş arasındaki hastalar çalışmaya alınmıştır. Temel immünoglobulin izotiplerinden herhangi birisinde yaşa göre normal değerlerden -2 standart sapmadan fazla düşüklük olması hipogamaglobülinemi olarak tanımlanmıştır.

Bulgular: Çalışmaya alınan 117 hastanın başvuru yaşı ortanca 11 ay [çeyrekler arası aralık (IOR): 6,7-33 ay], egzama başlangıç yaşı ortanca 3,5 ay (IOR: 2-6 ay), başvuru anındaki SCORingAtopicDermatitis skoru ortanca: 13,8 (IOR): 5-32] idi. Otuz altı (\%30,8) hastada immünoglobulin izotiplerinden

Address for Correspondence: Burçin BEKEN MD, Trakya University Faculty of Medicine, Department of Pediatrics, Department of Pediatric Immunology and Allergy, Edirne, Turkey

Phoe: +90 5057213496 E-mail: burcinbeken@gmail.com ORCID ID: orcid.org/0000-0001-7677-7690

Received: 19.04.2021 Accepted: 12.07.2021

๑Copyright 2021 by the Tekirdağ Namık Kemal University Faculty of Medicine / Namık Kemal Medical Journal published by Galenos Publishing House. 
en az birinde düşüklük olup immünoglobulin (Ig)-A, M ve G düşüklüğü sırasıyla; 21 (\%17,9), 18 (\%15,5) ve 23 (\%19,7) hastada saptandı. Hafif ve orta-ağır egzama grupları arasında başvuru yaşı, egzama başlangıç yaşı, ailede alerjik hastalık öyküsü, sigara maruziyeti, aeroalerjen duyarlılığı, besin alerjisi, hipogamaglobülinemi saptanan hasta sayısı ve $\operatorname{lgA}, \mathrm{M}$ ve $\mathrm{G}$ düzeyleri açısından bir fark bulunmazken, orta-ağır egzama grubunda erkeklerin daha fazla sayıda olduğu ve eozinofil yüksekliği saptandı.

Sonuç: $A D$ hastalarında egzama şiddetinden bağımsız olarak immünoglobulin düzeylerinin değerlendirilmesinin primer immün yetmezlik ayrımının yapılması ve hastaların süt çocukluğunun geçici hipogamaglobulinemisi açısından takibi için önemli olduğu düşünülmüştür.

Anahtar Kelimeler: Atopik dermatit, egzama, hipogamaglobülinemi

\section{INTRODUCTION}

Atopic dermatitis (AD) is the most common chronic inflammatory skin disease of the childhood. Its incidence in Turkey ranges from 9.6 to $17.1 \%$ in population screening studies ${ }^{1,2}$. In a recently published birth cohort study, it was found to be $12.8 \% \%^{3}$. Although the pathophysiology of the disease has not been clearly revealed, it is thought to occur as a result of a complex interaction between genetic, environmental, immunological and epidermal factors ${ }^{4}$. Factors exacerbating eczema include physical/chemical irritants, infections such as Staphylococcus aureus and Herpes simplex virus, aeroallergens and food allergens. Although AD-like skin rashes can be seen in immunodeficiencies such as Hyper IgE syndrome (HIES), Wiscott-Aldrich Syndrome and Omenn Syndrome, it has been reported that there is an increase in the frequency of $A D$ in patients with selective immunoglobulin A $(\lg A)$ deficiency and common variable immunodeficiency ${ }^{5}$. Considering that transient hypogammaglobulinemia of infancy (THI) is a factor that aggravates eczema in AD patients, intravenous immunoglobulin (IVIG) treatment was given to 6 patients with hypogammaglobulinemia, who did not respond to standard treatment, by Breslin et al. ${ }^{6}$, and clinical improvement was achieved in five of them. In our study, it was aimed to determine the frequency of hypogammaglobulinemia in patients with $A D$ and to examine the relationship between eczema severity and immunoglobulin levels.

\section{MATERIALS AND METHODS}

\section{Selection and Descripotion of Cases}

The data of patients aged 0-18 years who were diagnosed with AD between January 2015 and August 2018 at Trakya University Faculty of Medicine, Department of Pediatric Allergy and Immunology were analyzed retrospectively. Ethics committee approval dated 25.02.2019 and numbered 107 was obtained from Trakya University Scientific Research Ethics Committee for the study.

The diagnosis of $A D$ was made according to the diagnostic criteria of Hanifin and Rajka ${ }^{7}$. Demographic characteristics of the patients such as age, gender, age of onset of eczema, way of delivery, duration of breastfeed, history of formula feeding, smoking exposure and parental atopy history, hemogram, serum total $\lg G, \lg A, \lg \mathrm{M}$ and $\lg \mathrm{E}$ levels, peripheral blood eosinophil counts, skin prick test and nutrient challenge test results were evaluated. The SCORingAtopicDermatitis (SCORAD) ${ }^{8}$ index was used to assess disease severity; AD was classified as $<25$ mild, 25-50 moderate, $>50$ severe AD.

\section{Definition of Hypogammaglobulinemia}

In the evaluation of serum immunoglobulin levels, the values determined by Bayram et al. ${ }^{9}$ in healthy Turkish children were taken as reference. Hypogammaglobulinemia was defined as a decrease in any of the major immunoglobulin isotypes ( $\mathrm{lg} G, \lg \mathrm{A}$ and $\lg \mathrm{M})$ by more than -2 standard deviations from the normal values for this age. Patients with primary immunodeficiency and those with diseases that might cause secondary hypogammaglobulinemia (nephrotic syndrome, intestinal lymphangiectasia, protein-losing enteropathy, malnutrition, Epstein-Barr virus infection, cytomegalovirus infection) or those taking medication (antiepileptic drugs, systemic corticosteroids) were excluded.

\section{Statistical Analysis}

Statistical analyses were performed using Statistical Package for the Social Sciences version 25.0. Whether the data were normally distributed or not was evaluated with histogram and Kolmogorov-Smirnov test. The categorical data of the mild and moderate-severe AD groups were compared with the chisquare test, and the numerical data were compared with the Mann-Whitney U test. Correlation between immunoglobulin levels and SCORAD score was evaluated with the Spearman correlation test. In order to examine the factors affecting the severity of $A D$, variables that were found to be significant in univariate analyses and those that were thought to be clinically significant were included in the multiple logistic regression model. Cases with the $p$ value below 0.05 were considered statistically significant.

\section{RESULTS}

During the study dates, a total of 327 patients were diagnosed as $A D$ in our department, and 210 (64.2\%) of these patients were excluded from the study due to lack of data. For 117 
patients included in the study, the median age at presentation was 11 months [interquartile range (IOR): 6.7-33 months], the median age for the onset of eczema was 3.5 months (IQR: 2-6 months), the median SCORAD at admission was 13.8 (IQR: 5-32). Demographic and clinical characteristics of the patients are given in Table 1.

Thirty-six (30.8\%) patients had a decrease in any of $\lg \mathrm{A}_{\text {, }}$ $\lg \mathrm{M}$ and $\lg \mathrm{G}$ isotypes, and decreased $\lg \mathrm{A}, \lg \mathrm{M}$ and $\lg \mathrm{G}$ were detected in 21 (17.9\%), 18 (15.5\%) and 23 (19.7\%) patients, respectively. When mild and moderate-severe eczema groups were compared in terms of clinical and laboratory findings, no difference was found between these two groups in terms of age at admission, age of onset of eczema, family history of allergic disease, smoking exposure, aeroallergen sensitivity, number of patients with low immunoglobulin levels, and IgA, $\operatorname{lgM}$ and $\lg \mathrm{G}$ values. No correlation was found between serum immunoglobulin levels and SCORAD $(r=-0.113, p=0.269$ for $\lg A, r=-0.175$ for $\lg M$ and $r=-0.168$ for $\lg G, p=0.099$ ). In the moderate-severe $A D$ group, there were more males and the eosinophil count was significantly higher, while lgE levels and food sensitivity were found to be slightly higher. Fifty-one patients underwent 62 food challenge tests, mainly milk and egg, and no difference was found between the eczema severity groups in terms of food allergy (Table 2).

When gender, age of eczema onset, parental history of atopy, eosinophilia, high $\lg \mathrm{E}_{\text {, }} \operatorname{low} \lg \mathrm{G}$, and allergen sensitivity were included in the logistic regression model, male gender [Odds ratio (OR): 3.16, 95\% confidence interval (Cl): 0.98-10.12, $\mathrm{p}=0.050$ ] and eosinophilia (OR: $3.26,95 \% \mathrm{Cl}: 0.95-11.16$, $\mathrm{p}=0.050$ ) were found to be associated with eczema severity (Table 3).

\section{DISCUSSION}

In addition to being the primary barrier against microorganisms and allergens, the skin constitutes one of the most important elements of the natural immune system through the cells it contains $^{10}$. In our study, immunoglobulin values were examined in order to evaluate immune functions in children with $A D$, and the frequency of hypogammaglobulinemia was found to be $30.8 \%$. However, no correlation was found between the severity of eczema and immunoglobulin levels. Considering the literature, in the study of Celiksoy et al." including 160 AD cases and 65 healthy controls, the frequency of hypogammaglobulinemia was found to be higher in the AD group than in the healthy controls $(27.5 \%$ and $5 \%$, respectively), and similar to our study, there was no correlation between immunoglobulin levels and eczama severity. In the study of Toyran et al. ${ }^{12}$, the frequency of hypogmaglobulinemia was reported as $50 \%$, no difference was found in the severity of eczema between patients with and without hypogammaglobulinemia, but a negative correlation was found between $\operatorname{IgA}$ and $\lg \mathrm{M}$ levels and SCORAD score. In our study, the frequency of hypogammaglobulinemia in patients with $A D$ was found similar to the literature.

In our study, it was observed that there were higher number of boys and the eosinophil count was higher in the moderatesevere $A D$ group. In the study of Akan et al. ${ }^{13}$ investigating the factors affecting the severity of $A D$, eosinophilia and allergen sensitization were found to be risk factors for severe eczema, but gender did not have any effect on the severity. In the study of Cansever and Oruç ${ }^{14}$, it was found that earlyonset $A D$, high eosinophil count, familial atopy history, and presence of food sensitization were associated with severe AD.

Table 1. Demographic and clinical characteristics of the patients

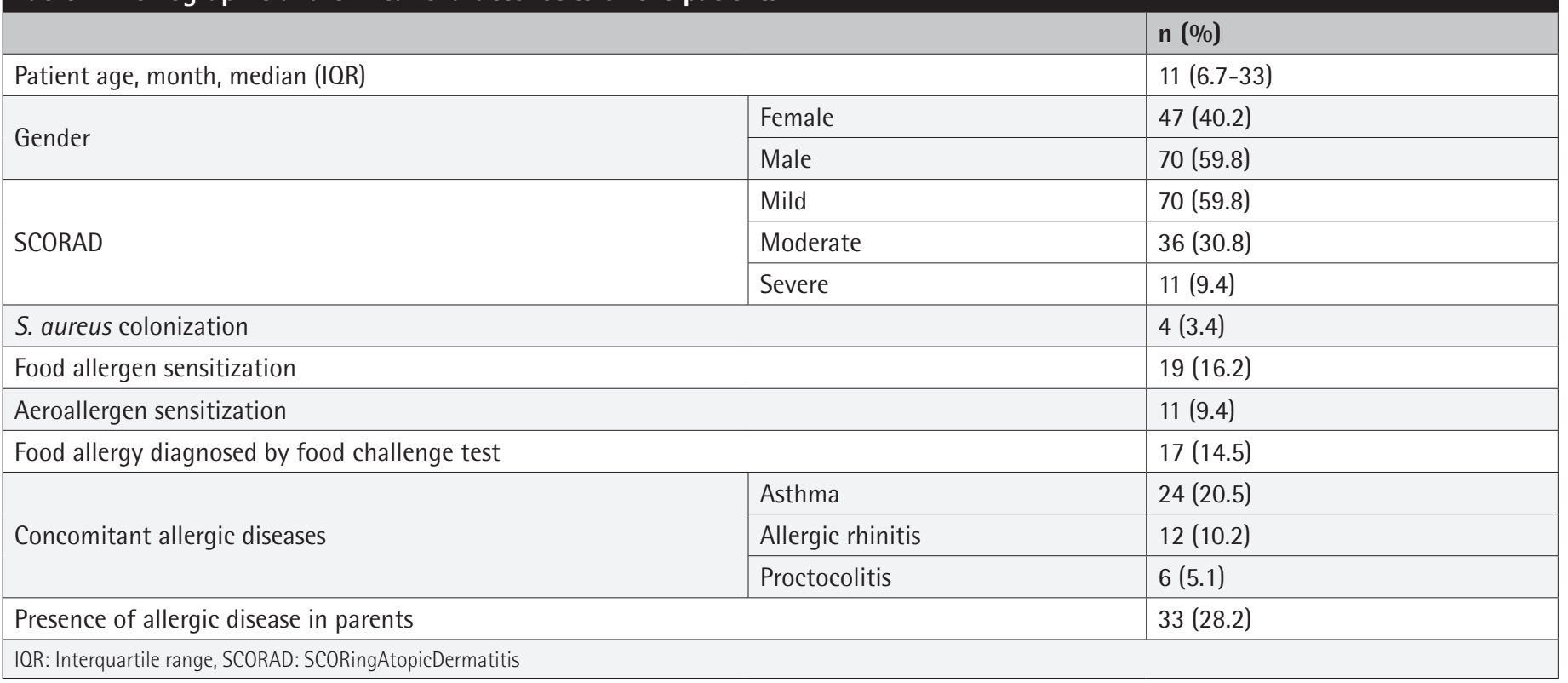




\begin{tabular}{|c|c|c|c|c|}
\hline & & Mild ( $n=72)$ & Moderate-severe $(n=45)$ & $\mathrm{p}$ \\
\hline \multicolumn{2}{|c|}{ Age (month)* } & $13.5(7.1-30.8)$ & $8(6.5-38)$ & 0.573 \\
\hline \multicolumn{2}{|c|}{ Age of onset of eczema (months) } & $3(1.5-6)$ & $4(2-6)$ & 0.230 \\
\hline \multirow{2}{*}{ Gender } & Female & 34 & 13 & \multirow{2}{*}{0.049} \\
\hline & Male & 38 & 32 & \\
\hline \multicolumn{2}{|c|}{ Family history of allergic disease } & 18 & 15 & 0.641 \\
\hline \multicolumn{2}{|c|}{ Smoking exposure } & 20 & 13 & 0.990 \\
\hline \multicolumn{2}{|c|}{ Food allergen sensitivity } & 8 & 11 & 0.052 \\
\hline \multicolumn{2}{|c|}{ Aeroallergen sensitivity } & 4 & 7 & 0.127 \\
\hline \multicolumn{2}{|c|}{ Food allergy proven by food challenge test } & 7 & 10 & 0.164 \\
\hline \multicolumn{2}{|c|}{$\lg A(<-2$ SD) } & 14 & 7 & 0.594 \\
\hline \multicolumn{2}{|c|}{$\operatorname{lgM}(<-2 \mathrm{SD})$} & 12 & 6 & 0.627 \\
\hline \multicolumn{2}{|c|}{$\lg G(<-2 \mathrm{SD})$} & 18 & 5 & 0.066 \\
\hline \multicolumn{2}{|c|}{$\lg \mathrm{A}(\mathrm{mg} / \mathrm{dL})^{*}$} & $30.3(19.7-65.7)$ & $37.3(23.8-63.9)$ & 0.482 \\
\hline \multicolumn{2}{|c|}{$\operatorname{lgM}(\mathrm{mg} / \mathrm{dL})^{*}$} & 81.7 (50.7-105.8) & $83.9(56.7-96.4)$ & 0.691 \\
\hline \multicolumn{2}{|c|}{$\operatorname{lgG}(\mathrm{mg} / \mathrm{dL})^{*}$} & $601.5(445.8-839.5)$ & $615(439.5-835.5)$ & 0.640 \\
\hline \multicolumn{2}{|c|}{$\operatorname{lgE}(\mathrm{IU} / \mathrm{L})^{*}$} & $18.4(7.5-73.4)$ & $50(9-206)$ & 0.059 \\
\hline \multicolumn{2}{|c|}{ Eosinophil count $\left(/ \mathrm{mm}^{3}\right)^{*}$} & $300(200-400)$ & $500(300-610)$ & $<0.001$ \\
\hline \multicolumn{5}{|c|}{$\begin{array}{l}\text { *Median (IOR) values are given. Chi-square test was used for categorical variables and Mann-Whitney } \mathrm{U} \text { test was used for numerical variables in the comparison of mild and } \\
\text { moderate-severe atopic dermatitis groups. }\end{array}$} \\
\hline \multicolumn{5}{|c|}{ IOR: Interquartile range, SCORAD: SCORingAtopicDermatitis, Ig: Immunoglobulin, SD: Standard deviation } \\
\hline
\end{tabular}

\begin{tabular}{|c|c|c|c|c|}
\hline \multirow[b]{2}{*}{ Gender } & \multirow{2}{*}{\begin{tabular}{|l}
$\mathbf{p}$ \\
0.050
\end{tabular}} & \multirow{2}{*}{\begin{tabular}{|l|} 
OR \\
3.16 \\
\end{tabular}} & \multicolumn{2}{|c|}{$95 \% \mathrm{Cl}$} \\
\hline & & & 0.98 & 10.12 \\
\hline Age of onset of eczema (months) & 0.919 & 1.00 & 0.97 & 1.02 \\
\hline Atopy history in the mother/father & 0.483 & 1.53 & 0.46 & 5.09 \\
\hline Eosinophilia & 0.050 & 3.26 & 0.95 & 11.16 \\
\hline Elevated $\lg \mathrm{E}$ & 0.476 & 1.58 & 0.44 & 5.66 \\
\hline Decreased IgG & 0.127 & 0.33 & 0.08 & 1.36 \\
\hline Food/Aeroallergen sensitivity & 0.354 & 0.55 & 0.15 & 1.93 \\
\hline
\end{tabular}

In a study that examined the relationship between eczema and gender, including 2,693 girls and 2.783 boys, eczema was found in $8.7 \%$ of the girls and $6.1 \%$ of the boys at the time of evaluation, and it was observed that the allergen sensitization was more in boys at the age of 5-7 years than in girls. In addition, only early-onset eczema was found to be associated with allergen sensitization in girls, while both early-onset and late-onset eczema were associated with allergen sensitization in boys ${ }^{15}$. Although the severity of eczema was not evaluated in this study, it can be indirectly assumed that the male gender has more severe course due to increased allergen sensitization due to skin barrier disorder in severe eczema.

Although the frequency of $\mathrm{THI}$ is not known precisely because it is a retrospective diagnosis, its incidence was reported as 23 per 1,000 live births in the largest series in the literature, and it was stated that $80 \%$ of the patients with THI had atopic disease or food allergy/intolerance ${ }^{16}$. Since eczematous skin lesions are frequently seen in primary immunodeficiencies such as selective IgA deficiency, common variable immunodeficiency, WiskottAldrich Syndrome and HIES, primary immunodeficiency should be kept in mind in patients with severe $A D^{17}$. In a study by Kasap et al. ${ }^{18}$, while characteristic facial appearance, delayed eruption of primary teeth, skin abscesses, rash in the neonatal period, and pneumatocele STAT- 3 were found to be predictors for HIES, mucocutaneous candidiasis and herpes infections were found to be more frequent in DOCK8 deficiency and these were rarely seen in patients with severe AD. Since none of the patients included in our study had clinical findings suggestive of primary immunodeficiency, the patients were evaluated as THI. 
Sumikawa et al. ${ }^{19}$ described two cases aged 4 and 6 months with eczema accompanied by $\mathrm{THI}$. They reported that, despite topical and systemic corticosteroid treatment, resistant eczema started to improve in the $10^{\text {th }}$ month when serum IgG levels started to increase and completely recovered about the $16^{\text {th }}$ month when IgG levels returned to normal. In the study of Yasuno et al. ${ }^{20}$, it was reported that 5 cases with hypogammaglobulinemia, whose eczema started at the age of 2 months, did not have exacerbation in their eczema after the immunoglobulin values returned to normal after the $12^{\text {th }}$ month. It has been suggested that a possible mechanism for the coexistence of $A D$ and hypogammaglobulinemia may be impaired skin barrier or loss of immunoglobulin from the GIS ${ }^{16,21}$. Moreover, it is also thought that THI may contribute to AD exacerbations due to inadequate response to secondary infections or fluctuations in inflammatory cytokines and CD4/CD8 ratio. ${ }^{20}$ However, the relationship between $T H I$ and $A D$ has not been clearly revealed yet. There are also studies showing that in patients with eczema associated with THI, the administration of IVIG treatment, provides clinical improvement and a decrease in $\lg \mathrm{E}$ levels in addition to antibiotics, topical or oral corticosteroid treatments against pathogenic microorganisms, primarily Staphylococcus aereus ${ }^{22,23}$.

\section{Study Limitations}

Although our study has limitations such as being retrospective and not having a control group, reference values according to age in healthy Turkish children were used for the definition of hypogammaglobulinemia. Thus, patients who fit the definition of hypogammaglobulinemia were correctly identified. The absence of primary immunodeficiency in any of the patients can also be considered as a strength of the study. Since primary immunodeficiencies accompanied by eczema were excluded, immunoglobulin levels in patients with isolated $A D$ were evaluated in our study.

\section{CONCLUSION}

In conclusion, the frequency of hypogammaglobulinemia is quite high in $A D$ patients, and it has been thought that the evaluation of immunoglobulin levels, regardless of the severity of eczema, is important for the differentiation of primary immunodeficiency and for the follow-up of the patients in terms of THI. Further studies with a larger number of patients are important in terms of revealing the relationship between $\mathrm{THI}$ and $\mathrm{AD}$.

\section{Ethics}

Ethics Committee Approval: The study were approved by the Trakya University of Scientific Research Ethics Committee (no: 107, date: 25.02.2019).
Informed Consent: Retrospective study.

Peer-review: Externally peer-reviewed.

\section{Authorship Contributions}

Concept: B.B., V.Ç., P.G.Ö., M.Y., Design: B.B., V.Ç., P.G.Ö., M.Y., Data Collection or Processing: B.B., Analysis or Interpretation: B.B., Literature Search: B.B., V.Ç., P.G.Ö., M.Y., Writing: B.B., V.Ç., P.G.Ö., M.Y.

Conflict of Interest: No conflict of interest was declared by the authors.

Financial Disclosure: The authors declared that this study received no financial support.

\section{Kaynaklar}

1. Civelek E, Sahiner UM, Yüksel H, Boz AB, Orhan F, Uner A, et al. Prevalence, burden, and risk factors of atopic eczema in schoolchildren aged 1011 years: a national multicenter study. J Investig Allergol Clin Immunol. $2011 ; 21: 270-7$.

2. Cetemen A, Yenigün A. Prevalences of asthma and allergic diseases inprimary school children in Aydin. Asthma Allergy Immunol. 2012;10:84-92.

3. Aksoy AG, Boran P, Karakoc-Aydiner E, Gokcay G, Tamay ZU, Devecioglu E et al. Prevalence of allergic disorders and risk factors associated with food allergy in Turkish preschoolers. Allergol Immunopathol (Madr). 2021;49:11-

4. Cork MJ, Danby SG, Vasilopoulos Y, Hadgraft J, Lane ME, Moustafa M, et al. Epidermal barrier dysfunction in atopic dermatitis. J Invest Dermatol. 2009;129:1892-908.

5. Relan M, Lehman HK. Common dermatologic manifestations of primary immune deficiencies. Curr Allergy Asthma Rep. 2014;14:480.

6. Breslin $M E$, Lin JH, Roberts $\mathrm{R}$, Lim KJ, Stiehm ER. Transient hypogammaglobulinemia and severe atopic dermatitis: Open-label treatment with immunoglobulin in a case series. Allergy Rhinol (Providence). 2016;7:69-73

7. Hanifin JM, Rajka G. Diagnostic features of atopic dermatitis. Acta Derm Venereol. 1980;92:44-7.

8. Severity scoring of atopic dermatitis: the SCORAD index. Consensus Report of the European Task Force on Atopic Dermatitis. Dermatology. 1993;186:23-31.

9. Bayram RO, Özdemir H, Emsen A, Türk Dağı H, Artaç H. Reference ranges for serum immunoglobulin ( $\lg G, \lg A$, and $\lg M)$ and $\lg G$ subclass levels in healthy children. Turk J Med Sci. 2019;49:497-505.

10. Egawa G, Kabashima K. Skin as a peripheral lymphoid organ: revisiting the concept of skin-associated lymphoid tissues. J Invest Dermatol. 2011;131:2178-85

11. Celiksoy MH, Topal E, Sancak R, Catal F, Sogut A. Relationship between hypogammaglobulinemia and severity of atopic dermatitis. Ann Allergy Asthma Immunol. 2014;113:467-9.

12. Toyran M, Akan A, Erkocoglu M, Vezir $E_{1}$ Azkur D, Civelek $E_{\text {, et al. The }}$ Relationship Between Low Serum Immunoglobulin Levels and Severity of Atopic Dermatitis in Young Children. Pediatr Allergy Immunol Pulmonol. 2013;26:152-6.

13. Akan A, Azkur D, Civelek E, Erkoçoğlu M, Yılmaz-Öztorun Z, Kaya A, et al. Risk factors of severe atopic dermatitis in childhood: single-center experience. Turk J Pediatr. 2014;56:121-6.

14. Cansever $M$, Oruç Ç. What plays a role in the severity of atopic dermatitis in children? Turk J Med Sci. 2021;51:2494-501. 
15. Möhrenschlager M, Schäfer T, Huss-Marp J, Eberlein-König B, Weidinger $S$, Ring J, et al. The course of eczema in children aged $5-7$ years and its relation to atopy: differences between boys and girls. Br J Dermatol. 2006;154:50513.

16. Walker AM, Kemp AS, Hill DJ, Shelton MJ. Features of transient hypogammaglobulinaemia in infants screened for immunological abnormalities. Arch Dis Child. 1994;70:183-6.

17. Aghamohammadi A, Moghaddam ZG, Abolhassani H, Hallaji Z, Mortazavi $H_{\text {, }}$ Pourhamdi S, et al. Investigation of underlying primary immunodeficiencies in patients with severe atopic dermatitis. Allergol Immunopathol (Madr). 2014;42:336-41.

18. Kasap N, Celik V, Isik S, Cennetoglu P, Kiykim A, Eltan SB, et al. A set of clinical and laboratory markers differentiates hyper-lgE syndrome from severe atopic dermatitis. Clin Immunol. 2021;223:108645.

19. Sumikawa Y, Kato J, Kan Y, Sato S, Yamashita T. Severe atopic dermatitis associated with transient hypogammaglobulinemia of infancy. Int J Dermatol. 2015;54:e185-7.
20. Yasuno T, Yamasaki A, Maeda Y, Fujiki A, Yagyu S. Atopic dermatitis and transient hypogammaglobulinemia of infancy improved simultaneously. Pediatr Int. 2007;49:406-8.

21. Nomura I, Katsunuma $T$, Tomikawa $M$, Shibata $A$, Kawahara $H$, Ohya $Y$ et al. Hypoproteinemia in severe childhood atopic dermatitis: a serious complication. Pediatr Allergy Immunol. 2002;13:287-94.

22. Duse M, lacobini M, Leonardi L, Smacchia P, Antonetti L, Giancane G. Transient hypogammaglobulinemia of infancy: intravenous immunoglobulin as first line therapy. Int J Immunopathol Pharmacol. 2010;23349-53.

23. Turner PJ, Kakakios A, Wong LC, Wong M, Campbell DE. Intravenous immunoglobulin to treat severe atopic dermatitis in children: a case series. Pediatr Dermatol. 2012;29:177-81. 